\title{
Effects of tissue plasminogen activator in experimentally induced peritonitis
}

\author{
Başak Erginel, M.D., ${ }^{1}$ Lütfiye Öksüz, M.D., ${ }^{2}$ Turgay Erginel, M.D., ${ }^{3}$ \\ Feryal Gün, M.D., ${ }^{1}$ Fatih Yanar, M.D., ${ }^{4}$ Nezahat Gürler, M.D., ${ }^{2}$ \\ Tansu Salman, M.D., ${ }^{1}$ Alaaddin Çelik, M.D. ${ }^{1}$ \\ ${ }^{1}$ Department of Pediatric Surgery, Istanbul University Istanbul Faculty of Medicine, Istanbul; \\ ${ }^{2}$ Department of Microbiology, Istanbul University Istanbul Faculty of Medicine, Istanbul; \\ ${ }^{3}$ Department of General Surgery, Istanbul Training and Research Hospital, Istanbul; \\ ${ }^{4}$ Department of General Surgery, Istanbul University Istanbul Faculty of Medicine, Istanbul
}

\begin{abstract}
BACKGROUND: We aimed to evaluate the microbiological and immunological effects of tissue plasminogen activator (tPA) in a rat model of peritonitis.

METHODS: Twenty-four male Wistar albino rats were divided equally into three groups. Peritonitis and thereafter laparotomy and partial omentectomy were performed in all rats. The control group $(C)$ had no further treatment. The antibiotics group (A) received metronidazole and ceftriaxone. The antibiotic and tPA group $(A+T)$ received the same antibiotics as well as tPA. For microbiological and immunological analysis, blood samples were obtained at the 24th hour, and peritoneal fluid samples were obtained at the 24 th and $72 n$ hours. On the fifth day after surgery, all rats were sacrificed, and the macroscopic findings of the peritoneal cavity were recorded.

RESULTS: The mean number of intraperitoneal abscesses was significantly higher in the control group and the lowest in the twotreatment group $(A+T)$. The levels of cytokines were not significantly different between groups. Giving tPA reduced the number and sizes of the abscesses with no significant difference in inflammatory response.
\end{abstract}

CONCLUSION: In this experimental peritonitis model, it can be postulated that tPA decreased abscess formation without exaggerating the inflammatory response.

Key words: Cytokine; intraperitoneal abscess; peritonitis; probiotic; tissue plasminogen activator (tPA).

\section{INTRODUCTION}

Secondary peritonitis is a life-threatening condition. It mostly occurs after disruption of the integrity of the gastrointestinal tract. Since intra-abdominal abscesses are the source of abdominal infection, their prevention is one of the goals in peritonitis therapy.

In intra-abdominal infections, the coagulation cascade is

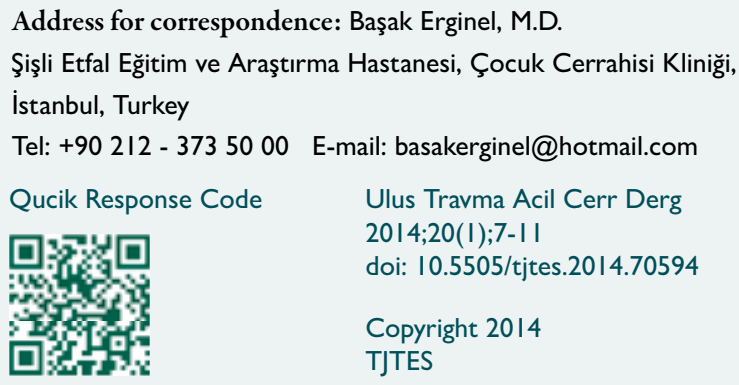

activated and fibrin deposits capture bacteria, preventing bacteremia and sepsis. Since fibrin deposition is an intrinsic element in abscess formation, it is logical to investigate fibrinolytic agents for peritonitis therapy. ${ }^{[1]}$

We aimed to evaluate the microbiological and immunological effects of tissue plasminogen activator (tPA) in a rat model of peritonitis.

\section{MATERIALS AND METHODS}

After obtaining the approval of the Animal Ethics Committee, 24 male Wistar albino rats (Institute of Experimental Medical Research and Application) weighing 300-350 g were divided equally into three groups of eight rats each. They were housed under controlled temperature $\left(2 \mathrm{I}^{\circ} \mathrm{C} \pm 2\right)$, lighting ( 12 -hour light/dark cycle) and humidity. For the peritonitis, we used the model modified by Buyne et al.," ${ }^{[2]}$ according to which, all rats received intraperitoneal Bacteroides fragilis (I04 CFU/ml) and Escherichia coli (I05 CFU/ml) through a 
fecal suspension processed from sterile stool. After one hour, all rats underwent laparotomies, their peritoneal cavities were debrided, and partial omentectomies were performed. The control group (C) had no further surgery and no further medical treatment. In the antibiotics group $(A)$, the rats received intramuscular metronidazole and ceftriaxone at 15 $\mathrm{mg} / \mathrm{kg}$ twice daily. The rats in the antibiotics and tPA group $(A+T)$ received the same antibiotics as well as tPA (Actilyse falcon, Boehringer, Ingelheim, Germany) (1.25 mg, in $2.5 \mathrm{mg}$ saline), which was injected percutaneously at I, 6 and 24 hours after surgery.

\section{Microbiological Analysis}

Peritonitis was graded by standard parameters. To evaluate peritonitis, microbiological analysis, such as culture and direct staining, was performed. For the evaluation of the immunologic parameters of peritonitis, cytokine levels in blood and peritoneal fluid samples were studied.

At the 24th hour after the induction of peritonitis, $500 \mu \mathrm{l}$ blood, and at the 72nd hour, peritoneal fluid samples were obtained and evaluated with BACTEC Peds Plus medium of BACTEC 9120 (bioMérieux, France) automation system. All samples were positively alarmed within 24 hours. Then, blood cultures were inoculated with $5 \%$ sheep-blood agar and chocolate agar (bioMérieux, France). At the end of the incubation period, colony counting was performed. For peritoneal sampling at the 24th and 72nd hour after inoculation, 5 $\mathrm{ml}$ saline was injected intraperitoneally and $2 \mathrm{ml}$ of it was removed. The samples were centrifuged at $750 \mathrm{~g}$ for 10 minutes and stored at $-80^{\circ} \mathrm{C}$, and immunological analysis of tumor necrosis factor (TNF)- $\alpha$, interleukin (IL)-I $\beta$, IL-6, and IL-I0 was performed on these samples.

\section{Macroscopic Analysis}

Two rats in the control group died within the first 24 hours. On the 5th day after surgery, all rats were sacrificed and the macroscopic findings regarding the peritoneal cavity (number, size and localization of the abscesses) were recorded. The abscesses were evaluated according to three main localizations, as subdiaphragmatic and right and left paracolic.

\section{Statistical Analysis}

Descriptive statistical methods were used for groups. Kolmogorov-Smirnov and Shapiro-Wilk normality tests were used for normality analysis. ANOVA and t-test methods were used to compare the groups to ensure that normal distribution was found. Kruskal-Wallis test was used for the variance analysis and Mann-Whitney U-test was used to compare those groups for which a normal distribution did not exist. Ninety-five percent was accepted as the confidence interval, and a p value $\leq 0.05$ was considered significant for the analysis.

\section{RESULTS}

\section{Macroscopic Findings}

In all rats, anorexia, piloerection and immobilization occurred after inoculation.

Loss of body weight: In all groups, there was a decrease in weights, especially in the first 24 hours after inoculation. The loss of body weight was similar between the groups, at $10 \%$.

Mean number of intraperitoneal abscesses: The mean number of intraperitoneal abscesses was significantly higher in group $\mathrm{C}$ than group $\mathrm{A}+\mathrm{T}$ (Table I).

Mean size of the abscesses: The mean size of the abscesses was larger in group $\mathrm{C}$ than group $\mathrm{A}+\mathrm{T}$ (Table 2 ).

Abscess localization: There was no significant difference in localization of the abscesses between groups (Table 3 ).

\section{Microbiological Analysis}

Bacterial culture: E. coli was the most isolated microorganism from samples from blood (after 24 hours' incubation) and peritoneal fluid (after 72 hours' incubation) in the control group. In the $A$ and $A+T$ groups, in addition to $E$. coli, bacteria such as Enterococcus, Bacillus and Klebsiella were also produced.

Cytokine levels: Cytokine levels of group $\mathrm{C}$ in comparison to group $A$ and group $A+T$ at the 24th hour of peritonitis are listed in Table 4. The difference was not significant except for IL-I $\beta$ : there was a significant decrease in IL-I $\beta$ in group $A+T$ in comparison to group $C(p=0.029)$.

In Table 5, cytokine levels of group $C$ in comparison to group $A$ and group $A+T$ at the 72 nd hour of peritonitis are listed. Again, there was a significant decrease in IL-I $\beta$ between group $C$ and group $A+T(p=0.020)$.

Table I. The mean number of abscesses

\begin{tabular}{ll}
\hline Groups & \\
\hline Control group (C) & 4.33 \\
Antibiotics group (A) & 1.63 \\
Antibiotics and tPA group (A+T) & 1.25 \\
\hline
\end{tabular}

Table 2. The mean size of the abscesses

\begin{tabular}{lcc}
\hline Groups & Sizes (mm) & SD \\
\hline Control group (C) & 8.83 & 3.76 \\
Antibiotics group (A) & 3 & 1.19 \\
Antibiotics and tPA group (A+T) & 2.5 & 1.3 \\
\hline SD: Standart deviation. & &
\end{tabular}

SD: Standart deviation. 
Table 3. Abscess localizations

\begin{tabular}{lcccc}
\hline Groups & Total number of abscess no & Subdiaphragmatic & Right paracolic & Left paracolic \\
\hline C & 24 & 8 & 5 & 11 \\
A & 13 & 4 & 3 & 6 \\
A+T & 10 & 3 & 5 & 2 \\
\hline
\end{tabular}

C: Control group; A: Antibiotics group; A+T: Antibiotics and tPA group.

In Table 6, TNF- $\alpha$ and IL-I $\beta$ values obtained 24 hours after inducing peritonitis are significantly different between group $A$ and group $A+T(p=0.00 I, p=0.07)$. These values are significantly lower in the group in which tPA was given.

Table 4. TNF- $\alpha$, IL-I $\beta$, IL-6, and IL- IO levels of the control group (C) in comparison to the other groups at the 24th hour of peritonitis

\begin{tabular}{lccccc}
\hline & C & A & p & A+T & p \\
\hline TNF- $\alpha$ & 21.93 & 18.14 & 0.852 & 5.77 & 0.228 \\
ILI- $\beta$ & 17.63 & 12.52 & 0.573 & 1.78 & 0.029 \\
IL-6 & 13.32 & 26.49 & 1.00 & - & 0.345 \\
IL-I0 & 72.08 & 33.26 & 0.95 & 15.12 & 0.18 I
\end{tabular}

C: Control group; A: Antibiotic group; A+T: Antibiotic and tPA group; TNF: Tumor necrosis factor; IL: Interleukin ( $\mathrm{P} \leq 0.05$ : significant).

Table 5. TNF- $\alpha$, IL-I $\beta, I L-6$, and IL- 10 levels of the control group (C) in comparison to the other groups at the 72 nd hour of peritonitis

\begin{tabular}{lccccc}
\hline & C & A & p & A+T & p \\
\hline TNF- $\alpha$ & 12.48 & 7.4 I & 0.573 & $7.4 I$ & 0.573 \\
ILI- $\beta$ & 11.17 & 2.72 & 0.59 & 2.61 & 0.020 \\
IL-6 & 5.36 & 9.06 & 0.95 & - & 0.662 \\
IL-I0 & 23.82 & 14.86 & 0.95 & 12.55 & 0.755
\end{tabular}

C: Control group; A: Antibiotic group; A+T: Antibiotic and tPA group; TNF: Tumor necrosis factor; IL: Interleukin ( $\mathrm{P} \leq 0.05$ : significant).

Table 6. TNF- $\alpha$, IL-I $\beta$, IL- 6 , and IL- 10 levels of the antibiotic group $(A)$ in comparison to the other groups at the 24th hour of peritonitis

\begin{tabular}{lccc}
\hline & A & A+T & P \\
\hline TNF- $\alpha$ & 18.14 & 5.77 & 0.001 \\
ILI- $\beta$ & 12.52 & 1.78 & 0.007 \\
IL-6 & 26.49 & - & 0.442 \\
IL-I0 & 33.26 & 15.12 & 0.05 I \\
\hline
\end{tabular}

C: Control group; A: Antibiotic group; A+T: Antibiotic and tPA group; TNF: Tumor necrosis factor; IL: Interleukin ( $\mathrm{P} \leq 0.05$ : significant).
The cytokine values at the $72 n d$ hour of peritonitis were not significantly different between the groups.

\section{DISCUSSION}

Peritonitis is still a life-threatening condition related to surgery, despite modern broad- spectrum antibiotics and advanced intensive care units. It is especially fatal in infants and newborns. Therefore, new treatments are being investigated. However, these treatments are still insufficient for cure. Antibiotics alone cannot be the definitive solution. Alternative treatments and surgical techniques are also being investigated, and among these new experimental drugs, tPA shows promising results.

There are many experimental peritonitis models. Among these experimental models, we preferred the one that was modified by Buyne et al. ${ }^{[2]}$ because of its effectiveness, low mortality rate, and ease. Until recently, experimental intraabdominal abscess models were provided with endogenous and exogenous contamination of the peritoneum. In endogenous contamination models, such as cecal ligation and puncture, the integrity of the gastrointestinal tract is disturbed, causing the inoculation of the bacteria to the peritoneum. In exogenous contamination, peritonitis is induced by injection of living, exogenous bacteria, liposaccaritis, or adjuvant substances, such as zymosan. The cecal ligation and puncture model is a well-defined method to induce peritonitis. The model is created by ligation of the cecum and puncture of the cecum with a standard needle under anesthesia. After this operation, the abdominal cavity is closed and subcutaneous fluid is given for resuscitation. Peritonitis is caused by cecal ischemia and the leakage of cecal contents into the abdominal cavity. ${ }^{[3,4]}$ However, cecal ischemia also aggravates the inflammatory response. Thus, the cecal ligation and puncture model is more appropriate for evaluating systemic inflammatory response, rather than local immune response..$^{[5]}$

Inoculation of a mixture of presterilized feces with $B$. fragilis and $E$. coli is an easily reproducible model to investigate residual abscesses after generalized peritonitis. Decreasing the percentage of feces and mixing it with sterile stool produces a model of septic shock. This model mimics the situation of perforated appendicitis, diverticulitis or secondary peritonitis due to colonic perforation. ${ }^{[6]}$ An experimental model to study the pathophysiology and treatment modalities of intra- 
abdominal abscesses is needed. Our model's mortality is directly relevant to the amount of $E$. coli used in the inoculation. The dosage of bacteria providing peritonitis is relevantly small and the abscess formation ratio is high. Since the peritonitis is created without laparotomy and anesthesia, the recovery period is short, and the risk of complications is lower.

During the experiment, the weight loss did not increase in the tPA group. Our results showed that rats were affected seriously by peritonitis, but these effects were not so much as to mask the local influence of peritonitis.

In the 24th and 72 nd hours, peritoneal fluid samples were obtained for culture analysis to demonstrate peritonitis. Although $E$. coli and $B$. fragilis were the only inoculated bacteria in all groups, the microbiological culture of the control group produced E. coli. In the tPA group, in addition to E. coli, bacteria such as Enterococcus, Bacillus and Klebsiella were also produced. This situation may be the result of antibiotics and tPA suppressing the normal flora and the overproduction of more resistant bacteria. The most variable microorganisms were produced in the group that received all three treatment modalities, which supports our hypothesis.

The number of abscesses was the highest in the control group. In the other groups, the number of abscesses was significantly lower, especially in the rats receiving tPA. Since the lowest number of abscesses was observed in the group that received tPA, it can be concluded that the addition of tPA might have positive effects on the treatment of peritonitis.

Most of the abscesses were located in the paracolic area. The drugs did not have any influence on the abscess localizations.

Proinflammatory mediators TNF- $\alpha$, IL-I $\beta$, and IL- 6 and the anti-inflammatory mediator IL- 10 were measured to evaluate the local inflammatory response. TNF- $\alpha$, IL-I $\beta$, and IL- 6 are the cytokines that initiate acute inflammation, and their increase is proportional to the degree of peritonitis. ${ }^{[7,8]}$ Since IL-10 decreases the production of proinflammatory cytokines, it is known as an anti-inflammatory cytokine. ${ }^{[7]}$ At the 24th hour after peritonitis induction, a strong local inflammatory reaction occurs, and all cytokines in the peritoneal fluid increase. Bacterial inoculation significantly increases the concentration of various inflammatory cytokines. Buyne et al. ${ }^{[2]}$ found a direct proportion between bacterial load in the abdomen in peritonitis and the number of cytokines in the peritoneal fluid. As mortality increases with bacterial density, mortality and the cytokine levels in the peritoneum are also correlated. We measured the cytokine levels in order to investigate whether the substances we used have any negative effects that could potentially increase mortality. However, the tPA treatment caused a significant increase in these cytokines. Moreover, in comparison to the control group and the group that received antibiotics, the tPA group demonstrated a drop in the IL-I $\beta$ responses measured from peritoneal fluid at the 24th and 72nd hours. In peritonitis therapy, applying tPA in addition to antibiotic can even decrease the IL-I $\beta$ production, which is an inflammatory cytokine. This result makes us think that even though tPA is an exogenous substance, it does not aggravate the local inflammatory response.

In 1994, van Goor et al.. ${ }^{[9]}$ claimed that tPA may have positive effects in experimental peritonitis. Later, Buyne et al. ${ }^{[0,1]}$ obtained some remarkable results regarding peritonitis treatment in a series of experimental studies. In the peritonitis model, conducted with rats, they showed that tPA has significantly positive effects on peritonitis, especially on abscess formation. Similarly, we have shown the positive effects of tPA. The previously mentioned investigators, in other research they conducted, also proved the effect of antibiotics to be limited. However, in our study, no major difference between tPA and antibiotics was observed.

In the peritonitis model of Buyne et al., ${ }^{[12]}$ the effect of tPA was investigated, and it was concluded that the level of cytokines is not affected by tPA treatment. Accordingly, in our research, there was no significant difference in the measurements of cytokine levels after either 24 hours or 72 hours. The hypothesis that these exogenous materials would exaggerate the inflammatory response was falsified by our results. In conclusion, tPA may decrease abscess formation, without exaggerating the inflammatory response.

\section{Conflict of interest: None declared.}

\section{REFERENCES}

1. Buyne OR, van Goor H, Verweij PE, Bleichrodt RP, Hendriks T. Timing and dose of tissue plasminogen activator to prevent abscess formation after surgical treatment of secondary peritonitis in the rat. Surg Innov 2009;16:299-305. CrossRef

2. Buyne OR, Bleichrodt RP, Verweij PE, Groenewoud HM, van Goor H, Hendriks T. A peritonitis model with low mortality and persisting intraabdominal abscesses. Int J Exp Pathol 2006;87:361-8. CrossRef

3. Hubbard WJ, Choudhry M, Schwacha MG, Kerby JD, Rue LW 3rd, Bland KI, et al. Cecal ligation and puncture. Shock 2005;24 Suppl 1:527. CrossRef

4. Baker CC, Chaudry IH, Gaines HO, Baue AE. Evaluation of factors affecting mortality rate after sepsis in a murine cecal ligation and puncture model. Surgery 1983;94:331-5.

5. Singleton KD, Wischmeyer PE. Distance of cecum ligated influences mortality, tumor necrosis factor-alpha and interleukin-6 expression following cecal ligation and puncture in the rat. Eur Surg Res 2003;35:48691. CrossRef

6. Nathens AB. Relevance and utility of peritoneal cultures in patients with peritonitis. Surg Infect (Larchmt) 2001;2:153-62. CrossRef

7. Haupt W, Riese J, Denzel C, Zowe M, Gusinde J, Siassi M, et al. Culture of human peritoneum--a new method to measure the local cytokine response and the effect of immunomodulators. Infection 1998;26:345-8.

8. Schein M, Wittmann DH, Holzheimer R, Condon RE. Hypothesis: compartmentalization of cytokines in intraabdominal infection. Surgery 1996;119:694-700. CrossRef 
9. van Goor H, de Graaf JS, Kooi K, Sluiter WJ, Bom VJ, van der Meer J, et al. Effect of recombinant tissue plasminogen activator on intra-abdominal abscess formation in rats with generalized peritonitis. J Am Coll Surg 1994;179:407-11.

10. van Goor H, Bom VJ, van der Meer J, Sluiter WJ, Geerards S, van der Schaaf $\mathrm{W}$, et al. Pharmacokinetics of human recombinant tissue-type plasminogen activator, administered intra-abdominally, in a rat peritonitis model. Eur Surg Res 1996;28:287-94. CrossRef
11. van Goor H, de Graaf JS, Kooi K, Bleichrodt RP. Gentamycin reduces bacteremia and mortality rates associated with the treatment of experimental peritonitis with recombinant tissue plasminogen activator. J Am Coll Surg 1995;181:38-42.

12. Buyne OR, Bleichrodt RP, van Goor H, Verweij PE, Hendriks T. Tissuetype plasminogen activator prevents formation of intra-abdominal $a b$ scesses after surgical treatment of secondary peritonitis in a rat model. Int J Colorectal Dis 2007;22:819-25. CrossRef

\title{
DENEYSEL ÇALIŞMA - ÖZET
}

\section{Deneysel peritonit modelinde doku plazminojen akivatörlerinin etkisi}

\section{Dr. Başak Erginel, ${ }^{1}$ Dr. Lütfiye Öksüz, ${ }^{2}$ Dr. Turgay Erginel, ${ }^{3}$ Dr. Feryal Gün, ${ }^{1}$ Dr. Fatih Yanar, ${ }^{4}$ Dr. Nezahat Gürler, ${ }^{2}$ Dr. Tansu Salman, ${ }^{1}$ Dr. Alaaddin Çelik}

\author{
${ }^{1}$ İstanbul Üniversitesi İstanbul Tıp Fakültesi, Çocuk Cerrahisi Anabilim Dalı, İstanbul; \\ ${ }^{2}$ İstanbul Üniversitesi İstanbul Tıp Fakültesi, Mikrobiyoloji Anabilim Dalı, İstanbul; \\ ${ }^{3}$ Istanbul Eğitim ve Araştırna Hastanesi, Genel Cerrahi Kliniği, İstanbul; \\ ${ }^{4}$ İstanbul Üniversitesi, İstanbul Tıp Fakültesi, Genel Cerrahi Anabilim Dalı, İstanbul
}

AMAÇ: Peritonit, cerrahi girişimler sonrasında sık görülen iltihabi bir reaksiyondur. Tedavide antibiyotikler ve cerrahi yer alır. Hayatı tehdit eden enfeksiyonların başında gelmesi nedeniyle alternatif tedavi yöntemleri araştııımaktadır. Bu çalışmada, sıçanlarda oluşturulan deneysel peritonit modelinde, doku plazminojen aktivatörlerinin (tPA) mikrobiyolojik ve immünolojik etkilerinin değerlendirilmesi amaçlandı.

GEREÇ VE YÖNTEM: Yirmi dört erkek Wistar albino sıçan sekizerli üç gruba ayrıldı. Fekal örnekler steril edildikten sonra, Bacteroides fragilis ( 04 $\mathrm{CFU} / \mathrm{ml}$ ) ve Escherichia coli ( $105 \mathrm{CFU} / \mathrm{ml}$ ) bakteri süspansiyonu eklenerek intraperitoneal olarak sıçanlara uygulandı. Bir saat sonra tüm sıçanlara laparotomi yapıldı, peritoneal kavite debride edildi ve parsiyel omentektomi uygulandı. Kontrol grubuna $(K)$ tedavi uygulanmadı, antibiyotik grubuna (A), günde iki defa intravenöz metronidazol+seftriakson tedavisi uygulandı. Antibiyotik ile birlikte doku plazminojen aktivatörü $(A+T)$ alan üçüncü gruba, cerrahiden sonraki I., 6. ve 24. saatlerde antibiyotiğin yanı sıra periton içine tPA enjekte edildi. Mikrobiyolojik ve immünolojik analizler için 24. saatte kan ve periton sıvısı, 72. saatte sadece periton sıvısı örneği alındı. Cerrahinin beşinci günü tüm sıçanlar öldürüldü ve peritoneal kavitedeki makroskopik bulgular (apse oluşumu, boyutu ve yerleşimi) kaydedildi.

BULGULAR: Ortalama periton içi apse sayısı kontrol grubunda en yüksek, üçüncü grupta $(A+T)$ en düşük sayıda bulundu. Gruplar arasındaki sitokin seviyelerinde anlamlı farklılık bulunmadı.

TARTIŞMA: Bu deneysel peritonit modelinde, doku plazminojen aktivatörü uygulanmasının enflamatuvar cevabı fazla etkilemeden apse oluşumunu bir miktar azalttı̆̆ı bulunmuştur.

Anahtar sözcükler: Antibiyotik; doku plazminojen aktivatörü; peritonit.

Ulus Travma Acil Cerr Derg 2014;20(I):7-II doi: 10.5505/tjtes.2014.70594 